\title{
Etik Örgüt Kültürünün Etik Tedarikçi Seçimine Etkileri Üzerine Bir Araştırma Çağrı AFŞAROĞULLARI ${ }^{1}$, Oylum KORKUT ALTUNA²
}

\author{
Öz
}

Küreselleşmenin bir sonucu olarak rekabet, işletmelerin ötesinde, tedarik zincirleri arasında gerçekleşmeye başlamıştır. Bu süreçte işletmelerin tedarik zincirleri kapsamında da etik konuları yönetsel bir bütünlükte ele almaları gerekliliği ortaya çıkmıştır. Bu araştırmada, etik örgüt kültürünün etik tedarikçi seçimine etkileri incelenmektedir. Araştırmada Goebel vd. (2012) çalışmasındaki model temel alınmıştır. Yargısal örnekleme yöntemi ve e-posta yoluyla anket kullanılarak LinkedIn aracılığı ile tespit edilen 2000 satınalma çalışanı araştırmaya dâhil edilmiş olup; 165 kullanılabilir anket elde edilmiştir. Araştırma sonuçlarına göre, etik örgüt kültürünün, etik tedarik seçimi üzerinde pozitif yönde etkili olduğu bulgusu elde edilmiştir.

Anahtar Kelimeler: Tedarik Zinciri Yönetimi, İş Etiği, Etik Örgüt Kültürü, Etik Tedarikçi Seçimi. Jel Kodu: M10, M14

\section{The Effects of Ethical Organizational Culture on Ethical Supplier Selection}

\section{Abstract}

Due to globalization, competition has started to appear between supply chains rather than the organizations. The requirement for the firms to handle ethical issues within a holistic managerial approach throughout their supply chains has emerged. This study focuses on the effects of ethical organizational culture on ethical supplier selection. This study is based on the model developed and tested by Goebel et al (2012). By judgmental sampling technique and online survey method 2000 buying professionals subscribed in LinkedIn were included in the data collection process and 165 usable surveys were collected. The results show that the ethical organizational culture has a positive significant effect on ethical supplier selection.

Key Words: Supply Chain Management, Business Ethics, Ethical Organizational Culture, Ethical Supplier Selection. Jel Codes: M10, M14

\section{GíRiş}

Entegre fonksiyonlar ile bir ucuna tedarikçilerin diğer ucuna da müşterilerin eklendiği tedarik zincirleri, küreselleşmenin bir sonucu olarak tedarik, üretim ve dağıtım süreçlerinin dünya geneline yayılması ile karmaşık bir yapıya bürünmüştür. İşletmeler tasarım ve pazarlama gibi anahtar yetenekler üzerine odaklanmış; üretim ve montaj ise işçiliğin ucuz olduğu dünya çapındaki tedarikçilere devredilmiştir. İşletmelerin üretim süreci için geçmişte temel olan çoğu faaliyet, günümüzde diğer kurumlar tarafından dünyanın farklı yerlerinde tamamlanmaktadır. (Neef, 2004: 12).
İşletmelerin ve tedarikçilerinin faaliyetlerinden kaynaklı sosyal ve çevresel sorunlar, Sivil Toplum Kuruluşları, aktivistler ve medyanın yakından takip ettiği bir konu haline gelmiştir. Yaşanan bu gelişmeler ışığında işletmelerin talep eden, yönlendiren, üretim için ödeme yapan ve sözleşmeden fayda sağlayan taraflar olarak tedarikçilerinin davranışlarından da sorumlu olmaları gerektiği anlayışı ortaya çıkmıştır (Neef, 2004: 61). Bununla beraber teknolojide yaşanan gelişmelere paralel olarak internet ve uydu televizyonu gibi iletişim araçlarının hızla yayılmasının neden olduğu saydamlık zorunluluğu, işletmelerin faaliyetlerinden kaynaklanan sosyal ve çevresel sorunları bir

\footnotetext{
1 Çağrı AFŞAROĞULLARI, İstanbul Üniversitesi, Sosyal Bilimler Enstitüsü, Tedarik Zinciri Yönetimi Anabilim Dalı, Beyazıt / İSTANBUL, c.afsarogullari@gmail.com ORCID: 0000-0002-0585-4924

2 Doç.Dr. Oylum KORKUT ALTUNA, İstanbul Üniversitesi, Siyasal Bilgiler Fakültesi, İşletme Bölümü, Beyazıt / İSTANBUL, oaltuna@istanbul.edu.tr
}

ORCID: 0000-0003-4871-1939 
sır gibi saklamalarını zorlaştırmanın ötesinde, çok riskli bir hale getirmiştir (Carter ve Rogers, 2008: 367). İşletmelerin başarısı hiç olmadığı kadar tedarikçilerinin performansına bağlı hale gelmiş; tedarikçilerinin çevre, çalışma koşulları ve ürün güvenliği gibi etik konulardaki kötü uygulamalarına "suç ortağı" sıfatı ile cezalandırılmaya başlanmışlardır (Neef, 2004: 35). Tedarikçiler, alıcı işletmeler, ürünleri satın alan tüketiciler ve yatırımcılar arasında bu işletmelerin itibarını ve dolayısıyla ticari değerini ciddi şekilde etkileyebilecek bir risk alanı oluşmuştur (Bekmen, 2014: 196). Üretim sorumluluğu mümkün olduğu kadar birer çözüm ortağı olarak görülen tedarikçilere kaydırılmış olup, bu tedarikçiler coğrafi olarak uzak lokasyonlarda yer alan bağımsız örgütsel / yasal yapılara sahip olsalar da; tedarik zincirleri boyunca etik sorumlulukların göz ardı edilemeyeceği açıktır.

$\mathrm{Bu}$ yaklaşım işletmelerin tedarik zincirlerinde ekonomik kriterler kadar etik konuları da yönetsel bir bütünlükte ele almalarına imkân sağlayacak örgütsel bir değişimi gerektirmektedir. $\mathrm{Bu}$ değişim hem işletme içerisinde hem de tedarik zincirleri boyunca uygun standartların geliştirilmesi ve sürdürülmesi kısacası, etik bir örgüt kültürü ve etik bir tedarik zinciri yapısı oluşturulması ile mümkündür. Tedarik zinciri yönetiminin temel faaliyetlerinden biri olan tedarikçi seçimi, etik bir tedarik zinciri yönetimi yapısı oluşturmanın en temel aracıdır. İşletmeler için önemli bir rekabet avantajı kaynağı olan tedarikçiler, gerekli özen gösterilmeden seçildiklerinde işletme itibarına ciddi zararlar verebilmektedir (Weele, 2014: 390). Dolayısıyla tedarikçiler geleneksel ekonomik kriterlerin yanında sosyal ve çevresel kriterler çerçevesinde değerlendirilerek seçilmelidirler. Şüphesiz ki, bu amacı gerçekleştirebilmek için işletmelerin öncelikle etik hususları kendi örgütleri içerisine entegre etmeleri ve etiği örgüt kültünün bir parçası haline getirmeleri gerekmektedir. Bu bakış açısıyla etik örgüt kültürüne sahip bir işletmenin satınalma çalışanlarının tedarikçi seçiminde, sosyal ve çevresel kriterleri gözetmek suretiyle etik kararlar almaları beklenmektedir.

Bu araştırmanın amacı, etik örgüt kültürünün etik tedarikçi seçimi üzerindeki etkilerini incelemektir. Ayrıca, hem etik örgüt kültürü hem de etik tedarikçi seçimi çok boyutlu kavramlar olduğundan, her iki değişkenin alt boyutları arasındaki ilişkilerin incelenmesi amaçlanmaktadır.

\section{KAVRAMSAL ÇERÇEVE}

Etik sözcüğü, Yunanca "ethos - ethikos" kelimesinden türetilmiş olmakla birlikte, "ahlak sistemi, gelenek, görenek, karakter, insan davranışı ve prensip" anlamına gelmektedir (Ülgen ve Mirze, 2004: 440). Etik, ahlaksal olanın özünü araştıran bir bilim olarak, insanın kişisel ve toplumsal yaşamındaki ahlaksal davranışlar ile ilgili "iyi nedir" veya "ne yapmalıyı??" gibi soruları ele alıp inceleyen felsefenin bir dalı olarak da tanımlanmaktadır (Akarsu, 1988: 74).

İş dünyasında alınan kararların ekonomik, teknolojik, politik, sosyal ve etik yönleri olabilir. Uzun vadede kurumların başarılı olabilmeleri güvenilir olmalarına, dolayısıyla tüm faaliyetlerinde etik hususları gözetmelerine bağlıdır (Așçıgil, 2001: 5). İş etiği, iş dünyasındaki etik problemleri inceler ve davranışlara rehberlik etmek üzere ilke ve standartlar geliştirmeye çalışır. Bu bağlamda iş etiği de etik gibi normatif ve betimleyici olarak ikiye ayrılmaktadır. Normatif iş etiği, etik ilke ve değerler çerçevesinde iş etiğine uygun eylem ve davranışların neler olması gerektiğini irdeleyerek, iş etiği kurallarını belirlemeye çalışır. Böylece yasal düzenlemelerin kapsamadığı durumlarda kullanılacak kurallar koyarak iş dünyasında güven ve istikrarın sağlanmasını amaçlar. Betimleyici iş etiği ise, iş dünyasında ortaya çıkan sorunları ve ilişkilerin ahlaki boyutunu inceler. Diğer bir deyişle, analitik bir yaklaşım ile mevcut ve yaygın olan etik içerikli davranış türleri ile bu davranışların olası nedenlerini irdeler (Berkman ve Arslan, 2009: 33-34).

İşletmeler insan ihtiyaçlarını karşılayarak kâr sağlamak amacı ile kurulmuş ekonomik 
varlıklar olmakla beraber, sosyal ve toplumsal hayattan ayrı düșünülemezler (Doğan, 2009: 180). İş etiğinin işletme içine ve işletme dışına yönelik olmak üzere iki boyutu bulunmaktadır. İşletme içine yönelik boyutu işletmenin çalışanlarını, tedarikçilerini, tüketicilerini ve rakiplerini içerirken; işletme dişına yönelik boyutu toplumun genelini, gelecek kuşaklara ait kaynakların etkin kullanılmasını ve israf edilmemesini içerir (Alayoğlu, 2015: 74). Dolayısı ile iş etiği çalışanlar, hissedarlar, tedarikçiler, baskı ve çıkar grupları, rakipler, tüketiciler ve hatta toplum ile işletme arasındaki ilişki ve etkileşimlerde neyin doğru, neyin yanlış olduğunu inceler ve tavsiyelerde bulunur.

Tedarik zinciri kapsamında iş etiği, hammadde tedarikinden başlayıp tüketiciye kadar uzanan yapı içerisindeki üyelerin faaliyetlerini kabul görmüş kurallar, çalışma ilkeleri ve yasalara uygun şekilde yürütmesi ve ekonomik hedefler gözetilirken, paydaş beklentilerinden kaynaklanan sosyal ve çevresel kaygıların da gözetilmesi olarak açıklanabilir.

$\mathrm{Bu}$ bağlamda uluslararası kurumlar ve iş dünyası, tedarik zincirlerinde insan hakları, çalışma koşulları, çevre ve yolsuzluk olmak üzere dört temel konu üzerine standartlar ve davranış kuralları geliştirmiştir. İşletmenin faaliyetlerinden olumlu ve olumsuz olarak etkilenen ve hakları söz konusu işletmenin faaliyetleri sonucunda olumlu veya olumsuz olarak etkilenen birey veya gruplar paydaş olarak nitelendirilmekte ve paydaş kavramı tedarikçileri de kapsamaktadır (Berkman ve Arslan, 2009: 49). Günümüzde tedarikçiler kısa süreli ve mübadele temelli ilişkiler kurulan birer kurum olmaktansa; karşılıklı güven, işbirliği ve uzun dönemli ilişkiler kurulan birer iş ortağı olarak görülmektedirler. Yakın ilişkiler kurmak, kurumlar ve onların tedarikçileri için performans arttırma ve kazan-kazan çözümlerine ulaşmada etkili bir iş stratejisi olarak kullanılmaktadır (Crane ve Matten, 2010: 393).

Tedarik zinciri yönetiminin temel faaliyetlerinden biri olan tedarikçi seçimi, etik bir tedarik zinciri yönetimi yapısı oluşturmanın en temel şartıdır. Tedarikçiler geleneksel olarak kalite, fiyat ve teslimat gibi kriterlerin yanında sosyal ve çevresel kriterler çerçevesinde, işletme itibarına zarar verebilme olasılıkları dikkate alınarak seçilmelidirler. Etik tedarikçi seçimi olarak adlandırılan bu sürecin; tedarikçi seçiminde çocuk işçilik, ayrımcılık, örgütlenme özgürlüğü, toplu pazarlık hakkı ve zorla çalıştırma gibi sosyal kriterlerin tedarikçi seçim sürecine dâhil edilmesini ifade eden "Sosyal Odaklı Etik Tedarikçi Seçimi" ve tedarikçi seçiminde tedarikçilerin çevre sorunları konusunda önleyici yaklaşımları, çevre dostu teknolojileri ve çevresel sorumluluğu arttıracak faaliyet ve oluşumları desteklemeleri gibi çevresel kriterlerin tedarikçi seçim sürecine dâhil edilmesini ifade eden "Çevresel Odakl Etik Tedarikçi Seçimi" olmak üzere iki alt boyutu bulunmaktadır (Goebel vd., 2012: 10).

\section{HIPPOTEZ GELISSTTIRME VE ARAŞTIRMA MODELI}

\subsection{Etik Tedarikçi Seçimi}

Tedarik zincirinde etik konular üzerine yapılan çalışmaların sayısı oldukça az olmakla beraber, tedarik zincirleri boyunca etik ilişkilerin geliştirilmesi ve yönetilmesi konusu, akademik yazında gelişen bir alan olarak yer almaya başlamıştır (Ferrell vd., 2013: 266). Bununla beraber, tedarik zinciri yönetimi ve tedarikçi seçiminin etik boyutu ile ilgili çalışmaların daha çok çevresel odaklı olduğu ve konunun sosyal boyutu veya her iki boyutun birlikte yer aldığı çalışmaların sayısının nispeten sınırlı olduğu gözlemlenmektedir (Goebel vd., 2012: 8).

"Sürdürülebilir Tedarik Zincirleri" konusunda yapılan araştırmaların tarandığı bir çalışmada; 1994 ile 2007 yılları arasında incelenen 191 çalışmanın 140'ının çevresel, 20'sinin sosyal ve 31'inin sosyal ve çevresel boyutların her ikisini de içerdiği tespit edilmiştir (Seuring ve Müller, 2008: 1702). "Yeşil ve Sürdürülebilir Tedarik Zincirleri" konusunda yapılan bir başka benzer araștırmada ise; 2002 ile 2012 


\section{Ç. AFŞAROĞULLARI - O. KORKUT ALTUNA}

yılları arasında yayınlanmış olan 124 yeşil tedarik zinciri yönetimi ve 56 sosyal sorumlu tedarik zinciri yönetimi konulu çalışma olduğu tespit edilmiștir (Ahi ve Searcy, 2013: 331). Tedarik zinciri alanında yaklaşık 50 yıldır yayın yapan Journal of Supply Chain Management isimli derginin son 10 ylldır yayınladığı 226 çalışmanın incelenmesi neticesinde; 6 çalışmanın Tedarik Zinciri Yönetiminde Etik, 5 çalışmanın Sosyal Sorumluluk ve 10 makalenin de Tedarik Zinciri Yönetiminde Sürdürülebilirlik konularıyla ilgili olduğu tespit edilmiştir. Bu araştırma sonucunda etik ve sosyal sorumluluk konularına odaklanan makalelerin büyük çoğunluğunun son 5 yılda yazıldığı görülmüştür (Ferrell vd., 2013: 267). "Sürdürülebilir Tedarik Zincirleri" konusunda yapılan bir literatür taramasında; 2008 ile 2013 yılları arasında Sosyal Sorumlu Tedarik Zinciri Yönetimi konulu 308 çalışma tespit edilmiş olup; bunların \% 69'u 2010 ile 2013 yılları arasında yayınlanmıştır (Touboulic ve Walker, 2015: 24). Son olarak "Tedarik Zincirlerinde Sürdürülebilir Tedarikçi Seçimi ve Değerlendirme" konusunda yaplan bir literatür taramasında; 2008 ile 2016 yılları arasında sürdürülebilirliğin ekonomik, sosyal ve çevresel kriterleri çerçevesinde ele alındığı 24 çalışma tespit edilmiştir (Luthra vd., 2017: 1688).

İlgili literatür incelendiğinde, tedarik zinciri yönetimi ve etik konusuna odaklanan sinırlı sayıda araștırmanın olduğu görülmektedir. Bunun yanında yapılan araştırmaların büyük çoğunluğunda etik kültür unsurlarının veya etik, sosyal sorumluluk ve sürdürülebilirlik ile ilgili uygulamaların işletmelere, tedarikçilere, alıcı-tedarikçi ilişkilerine ve satınalma sürecine etkilerinin incelendiği görülmektedir.

$\mathrm{Bu}$ konuda yapılan geçmiş çalışma bulguları incelendiğinde; etik davranışların işletmelerin imaj ve itibarını pozitif yönde etkilemekte olduğu ve tedarikçilerin etik dışı davranışlarının alıcı işletmelerin tedarikçi performansı konusundaki algılarını negatif yönde etkilediği görülmektedir (Carter, 1999: 202). İşletmedeki etik ve sosyal sorumlu yönde davranışların sosyal sorumlu satınalmanın uygulanmasını doğrudan etkilediği tespit edilmiştir (Park ve Stoel, 2005: 46). Sosyal sorumlu satınalma kavramı; çevre, çeşitlilik, insan hakları, güvenlik ve hayırseverlik olmak üzere beş boyutta ele alınmaktadır (Carter ve Jennings, 2000: 36). Yapılan araştırmalar işletme politikaları ve tüketici baskılarının sosyal sorumlu satınalma ile pozitif yönde ilişkili olduğu bulgularını ortaya koymaktadır (Carter ve Jennings, 2000: 36-37). İnsan merkezli işletme kültürünün, üst yönetimin liderliğinin, çalışanların sosyal sorumlu satınalma konusundaki girişimlerinin ve tüketici baskılarının sosyal sorumlu satınalma ile doğrudan ve pozitif yönde ilişkili olduğu görülmektedir (Carter ve Jennings, 2004: 166). Etik İklim ile Satınalmanın Sosyal Sorumluluğu ilişkisinin incelendiği başka bir çalışmada ise, üst yönetimin etik davranışlarının ve etik kodların uygulanmasının hem doğrudan, hem de etik kültür aracılığıyla dolaylı olarak satınalmanın sosyal sorumluluğunu etkilediği bulguları elde edilmiştir (Blome ve Paulraj, 2013: 567). Literatür incelendiğinde, sosyal sorumlu satınalmanın tedarikçi performansını doğrudan ve pozitif yönde, alıcı işletmeler ile tedarikçileri arasındaki güven ve işbirliğini ise dolaylı olarak etkilediği bulgularına rastlanmaktadır (Carter ve Jennings, 2002: 37). Ayrica sosyal sorumlu satınalmanın doğrudan olmasa da örgütsel öğrenme ve tedarikçi performansı aracılığıyla maliyetlerin azaltılması ile dolaylı olarak ilişkili olduğu bulgularına rastlanmaktadır (Carter, 2005: 186). Sosyal sorumlu tedarikçi seçiminin, Çin, BAE ve ABD'den seçilen 479 işletmenin satış gelirleri, son 3 yıllık satış artışı ve pazar payı boyutlarından oluşan ekonomik performanslarına etkisinin incelendiği bir çalışmanın sonuçlarına göre, sosyal sorumlu tedarikçi seçiminin işletmelerin ekonomik performansını doğrudan etkilediği görülmektedir (Thornton vd., 2013: 79). Etik Tedarikçi Seçimi bu çalışmanın bağımlı değişkeni olup; geçmiş çalışmalar ışığında 
sosyal odaklı ve çevresel odaklı olmak üzere iki boyut ile araştırmaya dâhil edilmiștir.

\subsection{Etik Örgüt Kültürü}

Etik örgüt kültürü; işletme içerisinde kabul edilebilir veya kabul edilemez unsurların neler olduğunun belirlenmesine yardım ederek, etik davranışları belirleyen faktör olarak tanımlanmaktadır (Trevino vd., 2001: 307). Etik örgüt kültürünü oluşturan boyutlar; üst yönetimin etik davranışları ne derecede önemsediği ve davranışları ile çalışanlara örnek olmalarını ifade eden "Üst Yönetimin Etik Davranışı”, "Etik Davranışları Teşvik Eden Ödül ve Ceza Sistemi”; etik kodların oluşturulması, iletilmesi ve uyulmasını ifade eden "Etik Kodların Uygulanması" ve üst yönetim tarafından çalışanlardan ne söyleniyorsa onu yapmalarının beklenmesini ifade eden "Otoriteye İtaat" olarak tanımlanmaktadır (Trevino vd., 2001: 313).

Etik örgüt kültürü unsurları ile etik davranışların desteklenmesiyle, bireysel davranışların daha etik olması beklenmektedir. Etik örgüt kültürünün etik davranışları etkilediği bilinmektedir (Trevino ve Weaver, 2001: 668). Dolayısıyla satınalma çalışanlarınca algılanan etik örgüt kültürünün, onların tedarikçi seçimi konusunda etik karar vermelerine pozitif yönde etkisinin olması beklenmektedir. Bu bağlamda, Etik Örgüt Kültürü araştırmanın bağımsız değișkeni olarak kabul edilmiş olup; aşağıdaki hipotez kurulmuştur:

H1: Etik örgüt kültürü etik tedarikçi seçimi üzerinde pozitif yönde etkilidir.

\subsection{1 Üst Yönetimin Etik Davranışı}

İşletme içerisinde etik yönetimin geliştirilmesi konusunda ilk adım üst yönetimin liderliği ve desteğidir. Birer rol model olan yöneticiler çalışanlara örnek olmalı ve etik davranışları desteklemelidir. İşletmeler üst kademe yöneticilerin norm ve değerlerini yansıtma eğilimindedirler (Özgener, 2014: 141). Üst yönetimin çalışanlar tarafından gözlenen ve onlara örnek teşkil eden davranışları, etik örgüt kültürünün oluşturulması konusunda önemli bir rol oynamaktadır (Trevino, 1990:
203). Adil davranmak, etik davranışlar sergilemek ve etik standartları dile getirmek gibi kişilerarası davranışlar, yöneticilerin etik davranışlarının temel özellikleri olarak tanımlanmaktadır (Weaver vd., 2005: 315).

Yapılan bir araştırmada; yöneticiler tarafından ortaya konan örnek davranışların çalışanları etik yönde davranma konusunda etkilediği tespit edilmiştir (Adam ve Rachman-Moore, 2004: 232). Başka bir araştırmada da benzer bir şekilde yöneticilerin etiği önemsediğinin, ciddiye aldığının ve etik ile kurumsal değerlere mümkün olduğunca öncelik verildiğinin çalışanlarca algılandığ çalışanların davranışlarının anlamlı bir şekilde etik yönde etkilendiği tespit edilmiştir (Trevino vd., 1999: 141).

Bir işletmede üst yönetim, etik davranışları ile çalışanlara etik davranmak konusunda örnek teşkil ediyorsa; üst yönetiminin etik davranışlarının tedarikçi seçiminde sosyal ve çevresel kriterleri gözeterek etik karar almaları konusunda satınalma çalışanlarına da pozitif yönde etkisinin olması beklenmektedir. Bu nedenle aşağıdaki hipotezler kurulmuştur:

H1a: Üst yönetimin etik davranışı sosyal odaklı etik tedarikçi seçimi üzerinde pozitif yönde etkilidir.

H1b: Üst yönetimin etik davranışı çevresel odaklı etik tedarikçi seçimi üzerinde pozitif yönde etkilidir.

\subsubsection{Etik Davranışları Teşvik Eden Ödül ve Ceza Sistemi}

Etik davranışlar, çalışanları belirli bir biçimde davranmaya özendiren ödüller ve belirli davranışlardan kaçınmaya yönlendiren cezalar aracılığg ile pekiştirilebilmektedir. Ödül bir görevin, hizmetin veya sorumluluğun yerine getirilmesi sonucu elde edilen kazanımlar olarak tanımlanmaktadır (Pitts, 1995: 11). Ödüllerin etik karar alma davranışı üzerinde, sonuç beklentisi aracılığı ile dolaylı bir etkiye sahip olduğu tespit edilmiștir (Trevino ve Youngblood, 1990: 379). Ceza ise, yöneticilerin negatif sonuç doğuran uygulamaları veya yönetimi altındakiler için 


\section{Ç. AFŞAROĞULLARI - O. KORKUT ALTUNA}

pozitif sonuçların geri alınması olarak tanımlanmaktadır (Trevino, 1992: 649).

Ödül ve cezanın işletmelerdeki etik davranışlar üzerinde anlamlı bir etkisinin olduğu bilinmektedir (Hegarty ve Sims Jr., 1978: 456). Yapılan araştırmalar, amaçlanan davranışlara ulaşmak için ödül kadar cezanın da gerekli olduğu sonucunu desteklemektedir (Arvey vd., 1984: 448-460). Ödül ve ceza sistemi çalışanlardan beklenen davranışlar konusunda onları teşvik eden güçlü birer araçtır. Bir işletme çalışanlarını etik davranmaları konusunda ödül ve ceza sistemi aracılığıyla teşvik ediyorsa; ödül ve ceza sisteminin tedarikçi seçiminde sosyal ve çevresel kriterleri gözeterek etik karar almaları konusunda satınalma çalışanlarına da pozitif yönde etkisinin olması beklenmektedir. Bu nedenle aşağıdaki hipotezler kurulmuştur:

H1c: Etik davranışları teşvik eden ödül ve ceza sistemi sosyal odaklı etik tedarikçi seçimi üzerinde pozitif yönde etkilidir.

H1d: Etik davranışları teşvik eden ödül ve ceza sistemi çevresel odaklı etik tedarikçi seçimi üzerinde pozitif yönde etkilidir.

\subsubsection{Etik Kodların Uygulanması}

Etik kodlar, işletme içerisinde ve işletmenin diğer kurumlar ile ilişkilerinde, işlerin hangi ilke ve esaslara göre yaplacağını, hangi davranışların kabul edilebilir ve hangi davranışların kabul edilemez olduğu konularında farklı etik ve ahlaki değerlere sahip olan bireylere rehberlik sağlamaktadır.

Yapılan bir araștırmada etik kodlara adaptasyonun etik davranışları teşvik etmede en etkili kriter olduğu tespit edilmiştir (Ross, 1988: 15). Diğer bir araştırmada ise; cevaplayıcıların \%93'ünün sosyal sorumluluk, çalışanların davranışları, yönetim ve örgüt kültürü konularındaki hedeflere ulaşmada en yararlı araç olarak etik kodları seçtiği tespit edilmiştir (Robin vd., 1989: 66-73). Etik kodlar çalışanların etik davranmanın önemi konusundaki farkındalıklarını ve etik davranışları etkilemektedir (Adams vd., 2001: 207). Etik kodlar ile çalışan davranışları arasındaki ilişkiyi inceleyen bir araştırmada etik dışı davranışların, etik kodları olan işletmelerde, olmayan işletmelere göre daha az yaygın olduğu tespit edilmiştir (Somers, 2001: 189).

Bir işletme, etik kodlar aracılığıyla çalışanlarını etik davranmaları yönünde etkiliyorsa; etik kodların uygulanmasının tedarikçi seçiminde sosyal ve çevresel kriterleri gözeterek etik karar vermeleri konusunda satınalma çalışanlarına da pozitif yönde etkisinin olması beklenmektedir. $\mathrm{Bu}$ nedenle aşağıdaki hipotezler kurulmuştur:

H1e: Etik kodların uygulanması sosyal odaklı etik tedarikçi seçimi üzerinde pozitif yönde etkilidir.

H1f: Etik kodların uygulanması çevresel odakl etik tedarikçi seçimi üzerinde pozitif yönde etkilidir.

\subsubsection{Otoriteye İtaat}

Yönetim, çalışanların otoriteye koşulsuz itaat edecekleri bir yönetim stratejisi yerine, onların etik olan davranışı sergileyebilecekleri bir yönetim stratejisi belirlemelidir. "Yönetim her zaman haklıdır" anlayışı organizasyonlarda etik kültürün oluşturulması konusunda büyük bir engeldir.

Yapılan bir araştırmada, insanların kendi değer ve inançlarını göz önünde bulundurmadan onlara söylenene harfiyen bağlı kalarak davranmaları konusundaki tepkileri incelenmiştir. Araştırma sonuçlarına göre; insanların kendi değerleri ile çatışsa da diğer insanlara zarar vermeyi kabul etme derecesinde otoriteye itaat ettikleri tespit edilmiştir (Milgram, 1974: 42). Başka bir araștırmada ise, benzer bir şekilde otoriteye itaatin etik dışı davranışların gözlenmesine etkisinin olduğu tespit dilmiştir (Trevino vd., 2001: 319). Otoriteye itaat etik sorunları raporlamada isteksizliğe neden olmakta ve etik dışı davranışları teşvik etmektedir (Weaver, 2004: 124).

Otoriteye itaatin bir organizasyonda etik dişı davranışların gözlenmesinde etkisi varsa; otoriteye itaatin tedarikçi seçiminde sosyal ve çevresel kriterleri gözeterek etik karar 
almaları konusunda satınalma çalışanlarına da negatif yönde etkisinin olması beklenmektedir. $\mathrm{Bu}$ nedenle aşağıdaki hipotezler kurulmuştur:

$H_{1 g}$ : Otoriteye itaat sosyal odakl etik tedarikçi seçimi üzerinde negatifyönde etkilidir.

$\boldsymbol{H}_{1 \mathrm{~h}}$ : Otoriteye itaat çevresel odakl etik tedarikçi seçimi üzerinde negatifyönde etkilidir.

Araştırmanın kavramsal modeli Şekil 1'de sunulmaktadır. Araştırmanın bağımlı (endojen) değişkeni; Sosyal Odakl Etik Tedarikçi Seçimi ve Çevresel Odakl Etik Tedarikçi Seçimi olmak üzere iki alt boyuttan oluşan Etik Tedarikçi Seçimi'dir. Araștırmanın bağımsız (eksojen) değişkeni ise; Üst Yönetimin Etik Davranışı, Etik Davranışları Teşvik Eden Ödül ve Ceza Sistemi, Etik Kodların Uygulanması ve Otoriteye İtaat olmak üzere dört alt boyuttan oluşan Etik örgüt Kültürü'dür.

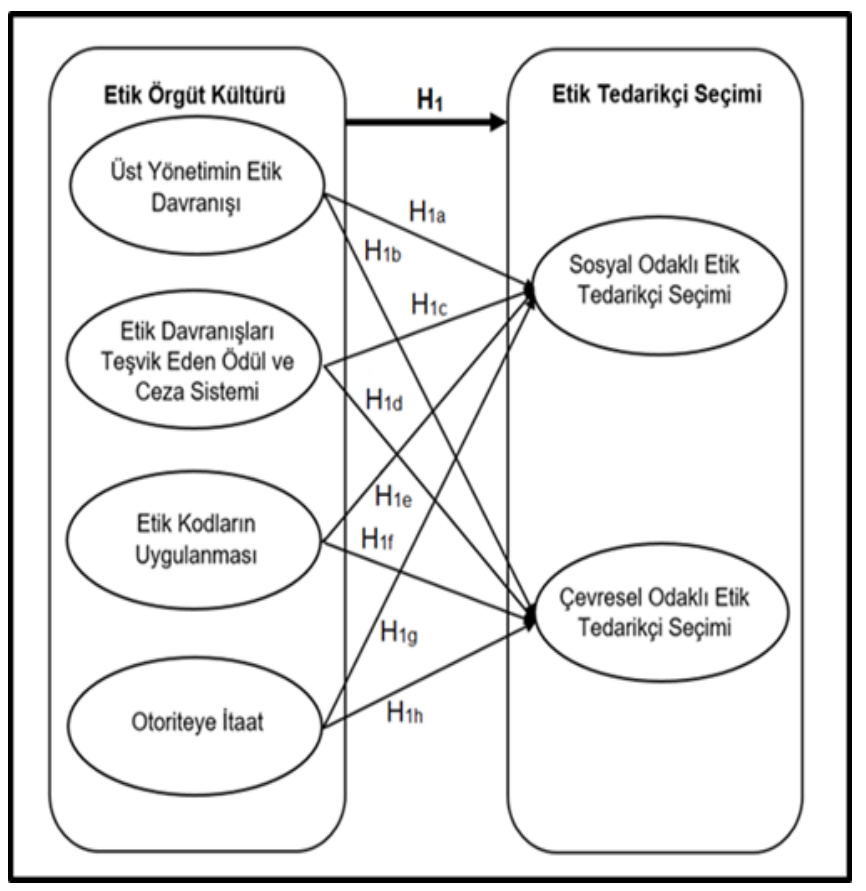

Şekil 1: Araştırma Modeli

\section{ARAŞTIRMA METODOLOJISI}

\section{1 Örneklem, Veri Toplama Tekniği ve Araștırmada Kullanılan Ölçekler}

Araștırmanın ana kütlesini iş dünyasındaki kişilerin diğer kişilerle iletişim kurmasını ve bilgi alışverişi yapmasını amaçlayan, aynı zamanda üyelerinin çalıştıkları işletme ve pozisyonları ile ilgili bilgilerinde paylaşıldığı profesyonel ve en geniş sosyal paylaşım platformu olan "LinkedIn" de kayitlı tüm satınalma çalışanları oluşturmaktadır. Araştırma kapsamına, tesadüfi olmayan örneklem yöntemlerinden yargısal örnekleme yöntemi kullanılarak, "LinkedIn" aracılığı ile tespit edilen 2.000 satınalma çalışanı dâhil edilmiştir. Ayrıca anket sorularının en başında, cevaplayıcılardan halen çalışmakta oldukları işletmenin adı, anketi cevaplayanın adı, soyadı ve unvanını belirtmesi istenmiştir. Bu filtre sorusu ile cevaplayıcıların satınalma çalışanı olup olmadıklarının tespitinin yapılması amaçlanmıștır.

Araştırmada veri toplama aracı olarak e-posta yoluyla anket formu kullanılmıștır. Anket formu üç bölümden oluşmaktadır. Birinci bölümde cevaplayıcıların satınalma çalışanı olup/olmadığını tespit etmeye yönelik ve ikinci bölümde cevaplayıcıların halen çalışmakta oldukları işletmelerin özelliklerine ilişkin sorular yer almaktadır. Üçüncü bölümde ise, etik örgüt kültürünün etik tedarikçi seçimine etkilerini ölçmek üzere hazırlanan iki değişkenli ölçek yer almaktadır.

Araştırmada kullanılan ölçekler Goebel $v d$. (2012) çalışmasından uyarlanmıştır. Ankette 7'li Likert tipi ölçek (1=Kesinlikle katılmıyorum, 7=Kesinlikle katılıyorum) kullanılmış ve cevaplayıcıların her bir ifadeye katılım seviyelerini belirtmeleri istenmiștir. Veri toplama süreci sonunda, LinkedIn üzerinden satınalma çalışanlarına gönderilmiş olan anketi 168 cevaplayıcı doldurmuştur. Toplanan anketler, veri girişi işleminden önce gözden geçirilmiş ve eksik veya hatalı doldurulan anketler ayıklanmıştır. Ayıklama işlemi, aynı kişi tarafından 7 günde tamamlanmıştır. Ayıklama işlemi sonucunda 168 anketten, 165 anket (\% 98) araştırmaya dâhil edilmiştir.

\subsection{Verilerin Analizi ve Araştırma Bulguları}

Araștırma bulguları ve değerlendirilmesi bölümünde, cevaplayıcıların çalıştıkları şirketlere ilişkin özelliklere, güvenilirlik 


\section{Ç. AFŞAROĞULLARI - O. KORKUT ALTUNA}

analizi sonuçlarına, araştırma değișkenlerine ait standart sapma ve aritmetik ortalama değerlerine, açımlayıcı ve doğrulayıcı faktör analizi sonuçlarına ve yapısal eşitlik modeli analizi sonuçlarına yer verilmiştir.

\subsubsection{Cevaplayıcıların Çalıştıkları Şirketlere İlişkin Özellikler}

Örneklem yapısını incelemek üzere cevaplayıcıların çalıștıkları şirketlere ilişkin özellikler, frekans ve yüzde oranları Tablo 1'de sunulmuştur.

Tablo 1: Cevaplayıcıların Çalıştıkları Şirketlere İlişkin Özellikler

\begin{tabular}{|c|c|c|c|}
\hline & $\begin{array}{c}\text { Değişkenler } \\
(\mathrm{N}=165)\end{array}$ & Frekans & Yüzde \\
\hline Şirketlerin türü & $\begin{array}{l}\text { Üretici } \\
\text { Toptancı } \\
\text { Distribütör } \\
\text { Perakendeci } \\
\text { Hizmet } \\
\text { Diğer }\end{array}$ & $\begin{array}{c}109 \\
3 \\
10 \\
4 \\
25 \\
14\end{array}$ & $\begin{array}{c}66.1 \\
1.8 \\
6.1 \\
2.4 \\
15.2 \\
8.5\end{array}$ \\
\hline $\begin{array}{c}\text { Şirketlerin } \\
\text { küreselleşme } \\
\text { düzeyi }\end{array}$ & $\begin{array}{l}\text { Dünya çapında faaliyet gösteren bir } \\
\text { organizasyon } \\
\text { Dünya çapında faaliyet gösteren bir } \\
\text { organizasyonun parçası veya } \\
\text { bölümü } \\
\text { Birden fazla ülkede bölgesel çapta } \\
\text { faaliyet gösteren bir organizasyon } \\
\text { Ulusal çapta birden fazla tesis } \\
\text { arasında faaliyet gösteren bir } \\
\text { organizasyon ten bir } \\
\text { Ulusal çapta tek tesisli bi } \\
\text { organizasyon } \\
\text { Diğer coğrafi organizasyonlar }\end{array}$ & $\begin{array}{l}24 \\
31 \\
27 \\
1\end{array}$ & $\begin{array}{l}31.5 \\
18.2 \\
14.6 \\
18.8 \\
16.4 \\
0.6\end{array}$ \\
\hline $\begin{array}{c}\text { Şirketlerin iş etiği } \\
\text { ve davranış } \\
\text { kurallarının varlığı } \\
\text { durumu }\end{array}$ & $\begin{array}{l}\text { Evet } \\
\text { Hayır } \\
\text { Geliștirilme Așamasında }\end{array}$ & $\begin{array}{c}140 \\
11 \\
14\end{array}$ & $\begin{array}{c}84.9 \\
6.7 \\
8.5\end{array}$ \\
\hline $\begin{array}{c}\text { Şirketlerin } \\
\text { tedarikçi } \\
\text { iş etiği ve davranış } \\
\text { kurallarının varlığ } \\
\text { durumu }\end{array}$ & $\begin{array}{l}\text { Evet } \\
\text { Hayır } \\
\text { Geliştirilme Așamasında }\end{array}$ & $\begin{array}{c}128 \\
20 \\
17\end{array}$ & $\begin{array}{l}77.6 \\
12.1 \\
10.3\end{array}$ \\
\hline $\begin{array}{c}\text { Şirketlerin tedarik } \\
\text { zinciri yönetiminde } \\
\text { iş etiği stratejisine } \\
\text { en çok etki eden } \\
\text { paydaş grubu }\end{array}$ & $\begin{array}{l}\text { Alıcı İşletmeler } \\
\text { Hükümet/Devlet } \\
\text { Medya } \\
\text { Sendikalar } \\
\text { Sivil Toplum Kuruluşları/Aktivist } \\
\text { Gruplar } \\
\text { Şirket Sahipleri/Hissedarları } \\
\text { Şirket Yöneticileri/Çalışanlar } \\
\text { Yatırımcılar } \\
\text { Tedarikçiler } \\
\text { Toplum } \\
\text { Tüketiciler }\end{array}$ & $\begin{array}{c}29 \\
17 \\
2 \\
1 \\
0 \\
\\
16 \\
35 \\
2 \\
40 \\
4 \\
19\end{array}$ & $\begin{array}{c}17.6 \\
10.3 \\
1.2 \\
0.6 \\
\\
0.0 \\
9.7 \\
21.2 \\
1.2 \\
24.2 \\
2.4 \\
11.5\end{array}$ \\
\hline
\end{tabular}

\subsubsection{Araştırmada Kullanılan Ölçeklere İlişkin Güvenilirlik Analizi Sonuçları}

Güvenilirlik analizi sonucunda, Cronbach's Alpha değerlerinin Etik Örgüt Kültürü için 0,920 ve Etik Tedarikçi Seçimi için 0,946 olduğu tespit edilmiştir. Elde edilen katsayılara dayanarak güvenilirlik düzeylerinin oldukça yüksek olduğu görülmektedir (Nunnally, 1978: 245).

\subsubsection{Araştırmanın Değişkenlerine Ait Aritmetik Ortalama ve Standart Sapma Değerleri}

Araştırmada toplam 23 maddeden oluşan 2 değişken mevcut olup, aritmetik ortalama ve standart sapma değerleri Ek'1'de yer alan tabloda sunulmuştur. Ölçeğin nötr noktası (ne katıliyorum/ne katılmıyorum) 4 olarak belirlenmiş olup, cevaplayıcıların tüm sorulara verdikleri cevapların genel ortalamasının 5.16 olduğu tespit edilmiștir. Ek 1'de sunulan ortalamalar incelendiğinde $S 4, S 21, S 22$ ve $S 23$ değişkenleri haricindeki tüm değişkenlerin genel ortalamanın (5.16) üstünde ortalamalarla değerlendirildikleri görülmüştür. Ölçek maddeleri arasında en yüksek ortalamaya sahip değişkenlerin "Organizasyonumuzdaki üst yöneticiler düzenli olarak etiği önemsediklerini gösterirler", "Organizasyonumuzdaki üst yöneticiler etik yönde karar vermeye rehberlik ederler" ve "Organizasyonumuzdaki yönetim etik dişı davranışlar meydana geldiğinde, bu davranışları disipline ederler" olduğu gözlemlenirken; en düșük ortalamaya sahip değişkenin ise "Organizasyonumuzda patron her zaman haklıdır" olduğu tespit edilmiştir.

\subsubsection{Araştırma Değişkenlerine Ait Açımlayıcı Faktör Analizi Sonuçları}

Araştırma modelinde yer alan ölçeklerin boyutsal yapısının incelenmesi amacıyla SPSS 20.0 paket programı kullanılarak Açımlayıcı Faktör Analizi (AFA) uygulanmış ve Ek 1'de sunulmuştur. Analiz sonucunda, KMO değerlerinin 0.50 değerinin üzerinde olduğu (Etik Örgüt Kültürü=0,915; Etik Tedarikçi Seçimi $=0,898$ ) için örneklemin yeterli olduğu ve Bartlett küresellik testi sonuçlarına göre 
$(p<, 000)$ her iki değişken için de, maddeler arasında yeterli düzeyde ilișkinin olduğu tespit edilmiştir (Hair vd., 1998: 103).

Ek 1'de yer alan Açımlayıcı Faktör Analizi sonuçlarına göre, Etik Örgüt Kültürü değişkeninin toplam varyansin \%77.975'ini açıklayan 2 faktörden oluştuğu; Etik Tedarikçi Seçimi değişkeninin ise toplam varyansın \%75.987'sini açıklayan 1 faktörde toplandı̆̆ı tespit edilmiştir (Hair vd., 1998: 103). Açımlayıcı Faktör Analizi sonuçları ile orijinal faktör yapısı Ek 1'de karşılaştırılmıştır. Açımlayıcı Faktör Analizi sonucunda elde edilen faktör yapısı ile ölçeklerin orijinal faktör yapıları arasında fark olduğu görülmektedir. Araştırmanın amaç ve niteliği göz önünde bulundurularak, geçmiş çalışmalar ile karşılaştırma yapılabilmesi amacıyla araștırmanın sonraki așamalarında, Doğrulayıcı Faktör Analizi sonuçları da göz önünde bulundurularak, ölçeklerin orijinal faktör yapıları temel alınmıştır.

\subsubsection{Etik Örgüt Kültürünün Etik Tedarikçi Seçimi Üzerine Etkilerinin İncelenmesine Yönelik Doğrulayıcı Faktör Analizi ve Yapısal Model Testi Sonuçları}

Araştırma kapsamında görece küçük örneklem sayıları ile çalışmaya olanak sağlaması nedeni ile Kısmi En Küçük Kareler tabanlı YEM tercih edilmiş ve SmartPLS 3.2.7 paket programı kullanılmıştır. Kısmi En Küçük Kareler tabanlı YEM analiz süreci, ölçüm modelinin güvenilirlik ve geçerliliğinin tespiti ve değișkenler arasındaki ilișkileri inceleyen yapısal model sonuçlarının değerlendirmesi olmak üzere iki aşamalı olarak gerçekleștirilmiştir. Her bir değişkenin farklı bir kavramı ölçüp ölçmediğini belirleyebilmek için Ayırt Edici Geçerlilik test edilmiștir. Ayırt Edici Geçerlilik, Açıklanan Ortalama Varyans karekök değerlerinden oluşan köșe değerlerinin, köşe değerleri dışındaki değişken korelâsyonlarından büyük olması şartı ile sağlanmaktadır (Fornell ve Larcker, 1981: 46). Yapılan analizlerde, Etik Örgüt Kültürü (0.797) değişkeninin bu şartı sağlamadığı görüldüğünden, Doğrulayıcı Faktör Analizi uygulanarak ölçümlerin ilgili kavramlar üzerindeki standardize edilmiş yüklemeleri hesaplanmiș ve $S 21(-0,097), S 22(-0,368)$ ve $S 23(-0,259)$ dişındaki her bir maddenin, kendi yapısı içerisinde 150 örneklem için önerilen 0.45 değerinden büyük olarak yüklendiği tespit edilmiştir (Hair vd., 1998: 112). Dış model tahminlerinin güvenilirliği ve geçerliliği sağlanamadığı için analizler 0.45 değerinden küçük olarak yüklenen üç madde çıkarılarak tekrarlanmış ve Tablo 2'de sunulan değerler elde edilmiştir. Tablo 2'de Açlklanan Ortalama Varyans karekök değerlerinden oluşan köşe değerlerinin, köșe değerleri dışındaki değişken korelâsyonlarından büyük olduğu ve Ayırt Edici Geçerliliklerinin sağlandığ görülmektedir. Araştırma modelinin güvenilirliğini test etmek için Bileşik Güvenirlik ve Cronbach's Alpha değerleri hesaplanmıştır. Tablo 2'de Bileșik Güvenirlik ve Cronbach's Alpha değerlerinin önerilen 0.70 değerinin üstünde olduğu görülmektedir (Nunnally, 1978: 245). Ayrıca, Açıllanan Ortalama Varyansın 0.50 değerinin üzerinde olması Yakınsak Geçerliliği için yeterli bir değerdir (Fornell ve Larcker, 1981: 46).

Tablo 2: Etik Örgüt Kültürünün Etik Tedarikçi Seçimi Üzerine Etkilerinin İncelenmesine Yönelik Modelin Güvenilirliği ve Ayırt Edici Geçerliliği

\begin{tabular}{|c|c|c|c|c|c|}
\hline & $\begin{array}{c}\text { Açılanan } \\
\text { Ort.Varyans } \\
\text { (AVE) }\end{array}$ & $\begin{array}{c}\text { Bileşik } \\
\text { Güvenirlik } \\
\text { (CR) }\end{array}$ & $\begin{array}{c}\text { Cronbach's } \\
\text { Alpha (CA) }\end{array}$ & $\begin{array}{c}\text { Etik Örgüt } \\
\text { Kültürü }\end{array}$ & $\begin{array}{c}\text { Etik } \\
\text { Tedarikçi } \\
\text { Seçimi }\end{array}$ \\
\hline $\begin{array}{c}\text { Etik Örgüt } \\
\text { Kültürü }\end{array}$ & 0.770 & 0.977 & 0.975 & $\mathbf{0 . 8 7 7}$ & \\
\hline $\begin{array}{c}\text { Etik } \\
\text { Tedarikçi } \\
\text { Seçimi }\end{array}$ & 0.760 & 0.957 & 0.946 & 0.859 & $\mathbf{0 . 8 7 2}$ \\
\hline
\end{tabular}

Doğrulayıcı Faktör Analizi uygulanarak ölçümlerin ilgili kavramlar üzerindeki standardize edilmiş yüklemeleri hesaplanmış ve her bir maddenin kendi yapısı içerisinde 150 örneklem için önerilen 0.45 değerinden büyük olarak yüklendiği tespit edilmiştir (Hair vd., 1998: 112). Bununla beraber faktör yükü sinıflandırmasına göre 0.71 değerinin üzerindeki faktör yükü mükemmel olarak 


\section{Ç. AFŞAROĞULLARI - O. KORKUT ALTUNA}

sinıflandırılmaktadır (Comrey ve Lee, 1992: 243). Değişkenlere ait en düşük faktör yükünün 0.713 (S1) olduğu tespit edilmiș olup; yapılan sinıflandırmaya göre değişkenlere ait faktör yüklerinin mükemmel seviyede olduğu söylenebilmektedir.

Bağımlı (endojen) değişkenin, bağımsız (eksojen) değişkence ne seviyede açıklandığını tespit etmek için bağımlı (endojen) değişkene ilişkin $\mathrm{R}^{2}$ değeri hesaplanmıştır. Etik Tedarikçi Seçimine ait $R^{2}$ değeri 0.738 olarak tespit edilmiştir. $\mathrm{R}^{2}$ değerine göre Etik Tedarikçi Seçiminin \% 74 oranında, Etik Örgüt Kültürü değişkenince güçlü seviyede açıklandığı görülmektedir (Chin, 1998a: 323).

Modelin tahmin kapasitesini ölçmek için Blindfolding yaklaşımı ile bağımlı (endojen) değişkene ilişkin $Q^{2}$ değeri hesaplanmıştır. Bağımlı (endojen) değişkenin $Q^{2}$ değerinin sıfırdan farklı olması, bu değişkenin tahmin edici anlamlılığının (tahmin kapasitesinin) göstergesidir. Etik Tedarikçi Seçimine ait $Q^{2}$ değeri 0.519 olarak tespit edilmiştir. Etik Tedarikçi Seçimi değişkeninin $Q^{2}$ değerine göre, modelin tahmin edici anlamlılık düzeyinin büyük olduğu söylenebilmektedir (Henseler vd., 2009: 305).

Araştırma modelinin uyum iyiliği istatistik değerleri Tablo 3'te sunulmuş olup; uyum iyiliğini test etmek için SRMR (Standardized Root Mean Square Residual Standartlaştırılmış Hata Kareleri Ortalamasının Karekökü), NFI (Normed Fit Index - Normlaştırılmış Uyum İndeksi) ve GoF (Goodness of Fit - Uyum İyiliği) değerleri hesaplanmıştır (Henseler vd., 2015: 9-10).

Tablo 3: Modele İlişkin Uyum İyiliği İndeksleri

\begin{tabular}{|c|c|c|}
\hline Uyum İndeksleri & $\begin{array}{c}\text { İndeks Sımır } \\
\text { Değeri }\end{array}$ & $\begin{array}{c}\text { öıçülen } \\
\text { Değer }\end{array}$ \\
\hline $\begin{array}{c}\text { SRMR } \\
\text { (Standardized Root Mean Square Residual) }\end{array}$ & $<0.08$ & 0.057 \\
\hline $\begin{array}{c}\text { NFI } \\
\text { (Normed Fit Index) }\end{array}$ & $>0.90$ & $\mathbf{0 . 7 7 5}$ \\
\hline $\begin{array}{c}\text { GoF } \\
\text { (Goodness of Fit) }\end{array}$ & $>0.36$ & 0.751 \\
\hline
\end{tabular}

$\mathrm{Bu}$ araştırmada SRMR değeri 0.057 olarak hesaplanmış olup, önerilen 0.08 değerinden küçüktür (Hu ve Bentler, 1998: 449). NFI değeri ise, 0 (uyum yok) ile 1 (mükemmel uyum) arasında değer almaktadır (Geoffrey ve Streiner, 2008: 223). NFI değeri, örneklem büyüklügü ile pozitif yönde ilişkili olup, örneklem büyüklüğünün küçük olduğu durumlarda NFI değeri 1'in altında olma eğilimindedir (Hu ve Bentler, 1998: 429). NFI değeri örneklem sayısına karşı hassas bir değer olduğundan, uyum seviyesi yüksek modellerde bile NFI değeri, iyi uyum için önerilen 0.90 değerinden daha küçük değerler alabilmektedir (Bentler ve Bonnet, 1980: 600). 165 örneklem ile görece küçük örneklem büyüklüğüne sahip bu araştırmada NFI değeri 0.775 olarak hesaplanmıștır. Son olarak açıklanan ortalama varyans değerlerinin (dış model) ortalaması ile $\mathrm{R}^{2}$ değerlerinin (iç model) ortalamasının geometrik ortalaması alınarak, GoF (Goodness of Fit) değeri hesaplanmiştır (Tenenhaus vd., 2004: 739742). GoF değeri 0 ile 1 arasında bir değer almakta olup, yüksek olması yol model tahmininin iyiliğine işaret etmektedir (Tenenhaus vd., 2004: 739-742). Bu araștırmada GoF değeri 0.751 olarak hesaplanmış olup, büyük oranda model uyumunun sağlandığı söylenebilir (Wetzels vd., 2009: 187).

Değişkenler arasındaki ilişkileri inceleyen yapısal modeli test etmek için Bootstrapping model tahmin yöntemi kullanılmıștır. Yapısal modele ait yol katsayıları ve $\mathrm{t}$ değerleri Bootstrapping yöntemi ile orijinal veriden 1000 kez aynı hacimli alt örneklem alınarak hesaplanmıştır. Yol katsayısının anlamlı kabul edilebilmesi için en az 0.20 ve ideal olarak 0.30'un üzerinde bir değer alması gerekmektedir (Chin, 1998b: xiii). Bununla beraber $t$ değerinin 3.291 'den büyük olması 0.001 seviyesinde, 2.576 'dan büyük olması 0.01 seviyesinde, 1.96 'dan büyük olması ise 0.05 seviyesinde istatistiksel olarak anlamlılığa işaret etmektedir (Hair vd., 2011: 145). Tablo 4 modele ait yol katsayısı, t değeri ve $p$ değerine göre hipotezin desteklenme durumunu göstermektedir. 
Tablo 4: Etik Örgüt Kültürünün Etik Tedarikçi Seçimi Üzerine Etkilerinin İncelenmesine Yönelik Yapısal Model Sonuçları

\begin{tabular}{|c|c|c|c|c|c|}
\hline \multicolumn{2}{|r|}{ Hipotezler } & $\begin{array}{c}\beta \text { yol } \\
\text { katsayısı }\end{array}$ & $\begin{array}{c}t \\
\text { değeri }\end{array}$ & $\begin{array}{c}p \\
\text { değeri }\end{array}$ & Sonuç \\
\hline $\mathrm{H}_{1}$ & $\begin{array}{cc}\text { Etik } \\
\text { Örgüt } \\
\text { Kültürü }\end{array} \rightarrow \begin{array}{c}\text { Etik } \\
\text { Tedarikçi } \\
\text { Seçimi }\end{array}$ & 0.859 & 36.022 & 0.000 & Destekleniyor \\
\hline
\end{tabular}

Tablo 4'te sunulan modele ait yol katsayısı, $\mathrm{t}$ değeri ve $p$ değeri göz önünde bulundurulduğunda, $\quad H_{1}$ hipotezi desteklenmektedir.

\subsubsection{Araştırma Değişkenlerine Ait Alt Boyutlara İlişkin Doğrulayıcı Faktör Analizi ve Yapısal Model Testi Sonuçları}

Araştırma değișkenlerinin alt boyutları arasındaki ilişkileri test etmek amacıyla Kısmi En Küçük Kareler tabanlı, iki aşamalı YEM analizi tekrar edilmiştir. Tablo 5'te Bileşik Güvenirlik ve Cronbach's Alpha değerlerinin önerilen 0.70 değerinin üstünde olduğu görülmektedir (Nunnally, 1978: 245). Tabloda görüldüğü gibi Açıklanan Ortalama Varyans karekök değerlerinden oluşan köșe değerleri, Etik Davranışları Teşvik Eden Ödül ve Ceza Sistemi (0.893) hariç, köşe değerleri dıșındaki değişken korelasyonlarından büyük olma şartını sağlamaktadır (Fornell ve Larcker, 1981: 46). Dolayısı ile genel olarak Ayırt Edici Geçerliliğin sağlandığı söylenebilmektedir.

Tablo 5: Araştırma Değişkenlerine Ait Alt Boyutlara İlişkin Modelin Güvenilirliği ve Ayırt Edici Geçerliliği

\begin{tabular}{|c|c|c|c|c|c|c|c|c|c|}
\hline & $\begin{array}{c}\text { Açık.Ort. } \\
\text { Varyans } \\
\text { (AVE) }\end{array}$ & $\begin{array}{c}\text { Bileşik } \\
\text { Güvenirlik } \\
\text { (CR) }\end{array}$ & $\begin{array}{c}\text { Cronbach's } \\
\text { Alpha (CA) }\end{array}$ & $\begin{array}{c}\text { Cevresel } \\
\text { Odaklı }\end{array}$ & $\begin{array}{c}\text { Etik } \\
\text { Kod }\end{array}$ & $\begin{array}{c}\text { Ödül } \\
\text { Ceza }\end{array}$ & Otorite & $\begin{array}{c}\text { Sosyal } \\
\text { Odaklı }\end{array}$ & $\begin{array}{c}\text { Üst } \\
\text { Yönetim }\end{array}$ \\
\hline $\begin{array}{c}\text { Çevresel } \\
\text { Odaklı }\end{array}$ & 0.923 & 0.973 & 0.958 & $\mathbf{0 . 9 6 1}$ & & & & & \\
\hline Etik Kod & 0.834 & 0.953 & 0.934 & 0.830 & $\mathbf{0 . 9 1 3}$ & & & & \\
\hline Ödül Ceza & 0.798 & 0.952 & 0.936 & 0.780 & 0.859 & $\mathbf{0 . 8 9 3}$ & & & \\
\hline Otorite & 0.770 & 0.908 & 0.865 & -0.274 & -0.210 & -0.269 & $\mathbf{0 . 8 7 7}$ & & \\
\hline $\begin{array}{c}\text { Sosyal } \\
\text { Odaklı }\end{array}$ & 0.760 & 0.927 & 0.893 & 0.831 & 0.782 & 0.730 & -0.282 & $\mathbf{0 . 8 7 2}$ & \\
\hline $\begin{array}{c}\text { Üst } \\
\text { Yönetim }\end{array}$ & 0.893 & 0.971 & 0.960 & 0.827 & 0.865 & 0.904 & -0.248 & 0.783 & $\mathbf{0 . 9 4 5}$ \\
\hline
\end{tabular}

Doğrulayıcı Faktör Analizi sonucunda her bir maddenin kendi yapısı içerisinde 150 örneklem için önerilen 0.45 değerinden büyük olarak yüklendiği tespit edilmiştir (Hair vd., 1998: 112). Değişkenlere ait en düşük faktör yükünün 0.731 (S21) olduğu görülmekte olup; yapılan sınıflandırmaya göre değişkenlere ait faktör yüklerinin mükemmel seviyede olduğu söylenebilir (Comrey ve Lee, 1992:243).

Değișkenler arasında çoklu doğrusal bağlantının var olup olmadığını tespit etmek için Varyans Artış Faktörü (Variance Inflation Factors-VIF) değerleri hesaplanmıştır. VIF değerlerinin önerilen sinır değer olan 10'dan küçük olması önemsiz bir çoklu doğrusal bağlantının göstergesidir (Hair vd., 1998: 220). Bağımsız (eksojen) değișkenlere ilișkin VIF değerleri 1.08 ile 6.50 arasında değişmekte olup, 10 sınır değerini aşmamaktadır.

Çevresel Odaklı Etik Tedarikçi Seçimine ait $R^{2}$ değeri 0.742 ve Sosyal Odaklı Etik Tedarikçi Seçimine ait $R^{2}$ değeri ise 0.666 olarak tespit 


\section{Ç. AFŞAROĞULLARI - O. KORKUT ALTUNA}

edilmiștir. Söz konusu verilere göre Cevresel Odaklı Etik Tedarikçi Seçiminin \% 74 ve Sosyal Odaklı Etik Tedarikçi Seçiminin ise \% 67 oranında bağımsız (eksojen) değişkenlerce güçlü seviyede açıklandı̆̆ı görülmektedir. Çevresel Odaklı Etik Tedarikçi Seçimine ait $Q^{2}$ değeri 0.643 ve Sosyal Odaklı Etik Tedarikçi Seçimine ait $Q^{2}$ değeri ise 0.472 olarak tespit edilmiştir. Bağımlı (endojen) değişkenlerin $Q^{2}$ değerlerine göre modelin tahmin edici anlamlılık düzeylerinin büyük olduğu söylenebilir (Henseler vd., 2009: 305).

Araştırma modelinin uyum iyiliği istatistik değerleri Tablo 6'da sunulmuş olup, SRMR değeri 0.064, NFI değeri 0.785, GoF değeri ise 0.764 olarak hesaplanmıştır ve büyük oranda model uyumunun sağlandığı söylenebilmektedir.
Değișkenler arasındaki ilişkileri inceleyen yapisal model Bootstrapping model tahmin yöntemi ile test edilerek modele ait yol katsayıları, $\mathrm{t}$ değerleri ve $\mathrm{p}$ değerlerine göre hipotezlerin desteklenme durumu Tablo 7'de gösterilmiş olup, sunulan modele ait yol katsayısı, t değeri ve p değerine göre; $\boldsymbol{H}_{1 \boldsymbol{1}}, \boldsymbol{H}_{\mathbf{1}}$, $\mathrm{H}_{1 e}$ ve $\mathrm{H}_{1 \mathrm{f}}$ hipotezleri desteklenmektedir.

Tablo 6: Modele İlişkin Uyum İyiliği İndeksleri

\begin{tabular}{|c|c|c|}
\hline Uyum İndeksleri & $\begin{array}{c}\text { İndeks Sınır } \\
\text { Değeri }\end{array}$ & $\begin{array}{c}\text { ölçülen } \\
\text { Değer }\end{array}$ \\
\hline $\begin{array}{c}\text { SRMR } \\
\text { (Standardized Root Mean Square Residual) }\end{array}$ & $<0.08$ & 0.064 \\
\hline $\begin{array}{c}\text { NFI } \\
\text { (Normed Fit Index) }\end{array}$ & $>0.90$ & $\mathbf{0 . 7 8 5}$ \\
\hline $\begin{array}{c}\text { GoF } \\
\text { (Goodness of Fit) }\end{array}$ & $>0.36$ & 0.764 \\
\hline
\end{tabular}

Tablo 7: Araştırma Değişkenlerine Ait Alt Boyutlara İlişkin Yapısal Model Sonuçları

\begin{tabular}{|c|c|c|c|c|c|c|}
\hline \multicolumn{3}{|c|}{ Hipotezler } & $\begin{array}{c}\boldsymbol{\beta} \text { yol } \\
\text { katsayısı }\end{array}$ & $\begin{array}{c}\mathbf{t} \\
\text { değeri }\end{array}$ & $\underset{\text { değeri }}{\text { p }}$ & Sonuç \\
\hline $\mathrm{H}_{1 \mathrm{a}}$ & Üst Yönetim & Sosyal Odaklı & 0.455 & 3.357 & 0.001 & Destekleniyor \\
\hline $\mathrm{H}_{1 \mathrm{~b}}$ & Üst Yönetim & Çevresel Odaklı & 0.438 & 3.592 & 0.000 & Destekleniyor \\
\hline $\mathrm{H}_{1 \mathrm{c}}$ & Ödül Ceza & Sosyal Odaklı & -0.089 & 0.631 & 0.528 & Desteklenmiyor \\
\hline $\mathrm{H}_{1 \mathrm{~d}}$ & Ödül Ceza & Çevresel Odaklı & -0.043 & 0.376 & 0.707 & Desteklenmiyor \\
\hline $\mathrm{H}_{1 \mathrm{e}}$ & Etik Kod & Sosyal Odaklı & 0.444 & 3.512 & 0.000 & Destekleniyor \\
\hline $\mathrm{H}_{1 \mathrm{f}}$ & Etik Kod & Çevresel Odaklı & 0.473 & 3.864 & 0.000 & Destekleniyor \\
\hline $\mathrm{H}_{1 \mathrm{~g}}$ & Otorite & Sosyal Odaklı & -0.100 & 1.651 & 0.099 & Desteklenmiyor \\
\hline $\mathrm{H}_{1 \mathrm{~h}}$ & Otorite & Çevresel Odaklı & -0.078 & 1.596 & 0.111 & Desteklenmiyor \\
\hline
\end{tabular}

\section{BULGULARIN DEĞERLENDİRİLMESİ}

$\mathrm{Bu}$ araştırmada etik örgüt kültürünün etik tedarikçi seçimine etkisiyle ilgili teorik olarak kurulan yapısal modelin geçerli olup olmadığ 1 incelenmiştir. Ayrıca, hem etik örgüt kültürü hem de etik tedarikçi seçimi çok boyutlu kavramlar olduğundan, alt boyutlar arasındaki ilişkiler de incelenmiştir.

Bulgular değerlendirildiğinde, etik örgüt kültürünün, etik tedarikçi seçimi üzerinde pozitif yönde etkili olduğu görülmektedir. $\mathrm{Bu}$ bulgu geçmiş çalışmalarda etik kültürün etik davranışları etkilediği yönündeki bulgular ile örtüşmektedir (Trevino ve Weaver, 2001: 668).

Araştırma sonuçlarına göre, üst yönetimin etik davranışı ve etik kodların uygulanmasının sosyal odakl etik tedarikçi seçimi ve çevresel odakl etik tedarikçi seçimi üzerinde pozitif yönde etkili olduğu görülmektedir. Bununla beraber etik davranışları teşvik eden ödül ve ceza sistemi ile otoriteye itaatin, etik tedarikçi 
seçimi değişkeninin her iki boyutu üzerinde de etkili olmadığı tespit edilmiștir.

Araştırma bulgularına göre, üst yönetimin karar ve eylemlerinde etiği gözetmeleri, sosyal odaklı etik tedarikçi seçimi ve çevresel odaklı etik tedarikçi seçimi üzerinde pozitif yönde etkilidir. İlgili alanda geçmiş çalışmalar incelendiğinde, üst yönetimin liderliği ile sosyal sorumlu satın alma arasında pozitif yönlü ilişkilere rastlanmaktadır ve bu araştırma sonuçları söz konusu geçmiş çalışmalar ile paralellik göstermektedir (Carter ve Jennings, 2004: 166; Blome ve Paulraj, 2013: 567). Goebel vd. (2012) tarafından yapılan çalışmada da, üst yönetimin etik davranışları ile sosyal sorumlu tedarikçi seçimi ve çevresel sorumlu tedarikçi seçimi arasında ayrı ayrı pozitif yönde ilişki olduğu bulgusu raporlanmaktadır. Ayrıca, araştırma örneklemini oluşturan 165 işletmenin 35'inde (\%21.2) tedarik zinciri yönetiminde iş etiği stratejisine en çok etki eden paydaş grubunun "Şirket yöneticileri/çalışanlar" olduğu da (Tablo 1) görülmektedir.

Araştırma örneklemini oluşturan 165 işletmenin 140 'ında (\%84.9) iş etiği ve davranış kurallarının mevcut olduğu (Tablo 1) görülmektedir. Araştırma bulgularına göre, satınalma çalışanlarınca etik kodların anlaşılması ve uygulanması, tedarikçi seçiminde etik karar almaları yani sosyal odaklı etik tedarikçi seçimi ve çevresel odaklı etik tedarikçi seçimi üzerinde pozitif yönde etkilidir. $\mathrm{Bu}$ bulgu, etik kodların uygulanmasının satınalmanın sosyal sorumluluğunu doğrudan etkilediğini ortaya koyan diğer çalışma sonuçları ile örtüşmektedir (Blome ve Paulraj, 2013: 567). Goebel vd. tarafindan 2012 yılında aynı konuda yürütülen araştırma bulgularına göre, etik kodların uygulanması ile çevresel sorumlu tedarikçi seçimi arasında pozitif yönde bir ilişki tespit edilmiş ancak etik kodların uygulanması ile sosyal sorumlu tedarikçi seçimi arasında pozitif yönde bir ilişkinin var olduğuna dair bulgu elde edilememiştir. Söz konusu araştırmadan farklı olarak, bu araștırmada etik kodların uygulanmasının sosyal odaklı etik tedarikçi seçimi üzerinde pozitif yönde etkili olduğu bulgusu elde edilmiştir.

Araştırma bulgularına göre, etik davranışları teşvik eden ödül ve ceza sistemi, sosyal odakl etik tedarikçi seçimi ve çevresel odakl etik tedarikçi seçimi üzerinde istatistiksel olarak anlaml bir etkiye sahip görünmemektedir. Araştırmanın örneklemini oluşturan 165 işletmenin 140'ında (\%84.9) şirket iş etiği ve davranış kurallarının mevcut olduğu (Tablo 1) görülmektedir. Etik kodlar çalışanlarca uyulması gereken minimum gereklilikleri tanımlamaktadır. Dolayısı ile etik kodlara uyum minimum gerekliliklerin yerine getirilmesi anlamina gelmekle birlikte, genellikle etik kodlara uyanlar ödüllendirilmemekte, fakat uymayanlar cezalandırılabilmektedir. Yani satınalma çalışanlarınca etik kodlara uyum onları cezalandırılmaktan korurken, herhangi bir ödül de sağlamamaktadır. $\mathrm{Bu}$ nedenle etik davranışları teşvik eden ödül ve ceza sisteminin sosyal odaklı etik tedarikçi seçimi ve çevresel odaklı etik tedarikçi seçimi üzerinde pozitif yönde etkili olduğuna dair bulguların elde edilememiş olabileceği söylenebilir. Bu bulgu, "Etik Kültürün Etik Tedarikçi Seçimine Etkileri" konulu araştırmanın bulgularıyla da örtüşmektedir. Söz konusu araştırmada da ödül ve ceza ile sosyal sorumlu tedarikçi seçimi ve çevresel sorumlu tedarikçi seçimi arasında pozitif yönde bir ilişkinin olduğuna dair bulgu elde edilmemiştir (Goebel vd., 2012: 13).

Son olarak otoriteye itaatin sosyal odakl etik tedarikçi seçimi ve çevresel odaklı etik tedarikçi seçimi üzerinde negatif yönde etkili olduğuna dair bir bulgu da elde edilememiștir. Araştırmanın örneklemini oluşturan 165 işletmenin 140'ında (\%84.9) şirket iş etiği ve davranış kurallarının var olduğu; 128'inde (\%77.6) tedarikçi iş etiği ve davranış kurallarının var olduğu ve yalnızca 16'sında (\%9.7) tedarik zinciri yönetiminde iş etiği stratejilerine en çok etki eden paydaş grubunun "şirket sahipleri/hissedarlar" olduğu (Tablo 1) görülmektedir. Dolayısıyla 


\section{Ç. AFŞAROĞULLARI - O. KORKUT ALTUNA}

165 işletmenin büyük çoğunluğunda profesyonel yönetim anlayıșının yerleşik olduğu ve bu nedenle satınalma çalışanlarından tedarikçi seçiminde otoriteye itaat etmelerinin beklenmeyeceği sonucu çlkarılabilir. Bu bulgu "Etik Kültürün Etik Tedarikçi Seçimine Etkileri" konulu araştırmanın bulgularıla kısmen örtüşmektedir. Söz konusu araştırmada otoriteye itaat ile sosyal sorumlu tedarikçi seçimi arasında negatif yönde bir ilişkinin var olduğuna dair bulgu elde edilmiş olmakla beraber; otoriteye itaat ile çevresel sorumlu tedarikçi seçimi arasında negatif yönde bir ilişkinin var olduğuna dair bulgu elde edilmemiştir (Goebel vd., 2012: 13).

\section{SONUÇ, ARAŞTIRMA KISITLARI ve ÖNERILLER}

$\mathrm{Bu}$ araştırmada, etik örgüt kültürünün etik tedarikçi seçimi üzerindeki etkileri incelenmiş ayrıca; hem etik örgüt kültürü hem de etik tedarikçi seçimi çok boyutlu kavramlar olduğundan, bu hipotez alt boyutlar açısından da incelenmiştir.

Yapılan literatür araştırmaları sonucunda, tedarik zinciri yönetimi üzerine yapılan ve ulaşılabilen kaynakların büyük çoğunluğunda; öncelikle çevre olmak üzere, iş sağlığı ve güvenliği, insan hakları gibi etik konuların ayrı ayrı ve aralarındaki ilişki göz önünde bulundurulmadan incelendiği; tedarikçi seçimi üzerine yapılan ve ulaşılabilen kaynakların büyük çoğunluğunda ise; çok kriterli karar vermede kullanılan yöntemler vasıtasıyla sosyal ve çevresel kriterlerin yer aldığı tedarikçi seçim problemi konusunda çalışıldığı saptanmıştır. Bunun yanında, kısıtlı sayıda kaynağın tedarik zinciri yönetimi ve iş etiğini bütünleșik olarak ele aldığı ve etik örgüt kültürü ile etik tedarikçi seçimi arasındaki ilişkiyi incelediği tespit edilmiştir. Tedarik zincirinde etik konular üzerine henüz kapsamlı literatür olmasa da, tedarik zincirleri boyunca etik ilişkilerin geliştirilmesi ve yönetilmesi devam eden ve gelişen bir ilgi alanı olarak karşımıza çıkmaktadır. Dolayısı ile bu araştırmada literatürdeki bu eksikliğin giderilmesi amaçlanmakta ve konunun yöneticiler açısından faydalı olacağı düşünülmektedir.

Günümüzde iş dünyasının kazanç odaklı olması yeterli görülmemekle birlikte, iş dünyasından etik kararlar alması yani, faaliyetlerinden kaynaklı negatif etkileri en aza indirmesi, tedarikçilerin sosyal ve çevresel konulardaki yaklaşımlarıyla ilgili sorumluluk alması beklenmektedir. $\mathrm{Bu}$ amacı gerçekleştirebilmek için şirketlerin öncelikle etiği örgüt kültünün bir parçası haline getirmesi gerekmekte ve etik örgüt kültürüne sahip bir şirketin satınalma çalışanlarının tedarikçi seçiminde etik kararlar alması beklenmektedir. Araştırma sonucu elde edilen bulgular, etik örgüt kültürünün etik tedarikçi seçimi üzerinde pozitif yönde etkili olduğunu göstermektedir. Etik örgüt kültürü; organizasyon içerisinde neyin kabul edilebilir veya neyin kabul edilemez olduğunun belirlenmesine yardım ederek, etik davranışları belirlemektedir. Dolayısıyla etik örgüt kültürü satınalma çalışanlarının tedarikçi seçiminde etik karar almaları yani sosyal ve çevresel kriterleri gözetmeleri üzerinde pozitif yönde etkilidir. Bunun yanında etik örgüt kültürü ve etik tedarikçi seçiminin alt boyutları için elde edilen bulgular, üst yönetimin etik davranışının ve etik kodların uygulanmasının sosyal odaklı etik tedarikçi seçimi ve çevresel odaklı etik tedarikçi seçimi üzerinde pozitif yönde etkili olduğunu göstermektedir. Üst yönetimin adil davranmak, etik değerlere mümkün olduğunca öncelik vermek gibi çalışanlar tarafından gözlenen ve onlara örnek teşkil eden davranışları etik örgüt kültürünün oluşturulması konusunda ilk adım olarak, sosyal odaklı etik tedarikçi seçimi ve çevresel odaklı etik tedarikçi seçimini üzerinde pozitif yönde etkilidir. Etik kodlar ise, işletme içerisinde ve işletmenin diğer kurumlar ile ilişkilerinde hangi davranışların kabul edilebilir ve hangi davranışların kabul edilemez olduğu, işlerin hangi ilke ve esaslara göre yapılacağı konularında bireylere rehberlik sağlayarak etik örgüt kültürünü desteklemekle birlikte, sosyal odaklı etik tedarikçi seçimi ve çevresel odaklı etik 
tedarikçi seçimini üzerinde pozitif yönde etkilidir. Elde edilen bulgular literatürde yer alan benzer çalışmaların bulgularını desteklemektedir.

Araştırma kapsamında zaman ve maliyet kısıtları açısından tesadüfi olmayan örnekleme yöntemlerinden yargısal örnekleme yöntemi tercih edildiğinden genelleştirilebilirlik kısıtı oluşturmaktadır. Ayrıca örnekleme sürecinde satınalma çalışanlarının halen çalışmakta oldukları işletmelerde ve tedarik zincirlerinde mevcut iş etiği uygulamalarına ilişkin sorular yöneltildiğinden gönderilen anketlerin cevaplanması konusunda tereddütler yaşandığı gözlenmiştir.
Bundan sonra yapılacak olan çalışmalarda etik örgüt kültürünün etik tedarikçi seçimine etkileri; işletmenin küreselleşme düzeyi, büyüklügü, faaliyet gösterdikleri sektör ve satınalma çalışanlarının demografik özellikleri gibi farklı değişkenler çerçevesinde incelenebilir. İşletmelerin küresel çapta alıcı ve tedarikçilerinin konuşlu oldukları bölgelerin modele dâhil edilmesi özellikle iş etiği konusunda tüketici bilincinin oluştuğu ülkelerde konuşlu alıcı işletmelerin veya işgücünün ucuz ve çevresel kaygıların olmadığı ülkelerde konuşlu tedarikçilerin, etik örgüt kültürünün etik tedarikçi seçimine etkilerinin incelenmesinde ne gibi etkilerinin olduğunun tespit edilebilmesine olanak sağlayacaktır.

\section{KAYNAKÇA}

Adam, A.M., Rachman-Moore, D. (2004). "The Methods Used to Implement an Ethical Code of Conduct and Employee Attitudes", Journal of Business Ethics, Vol. 54, Issue.3: 225-244.

Adams, J.S., Tashchian, A., Shore, T.H. (2001). "Codes of Ethics as Signals for Ethical Behavior", Journal of Business Ethics, Vol.29, Issue.3: 199-211.

Ahi, P., Searcy, C. (2013). “A Comparative Literature Analysis of Definitions for Green and Sustainable Supply Chain Management", Journal of Cleaner Production, Vol.52, No.4: 209-216.

Akarsu, B. (1988). Felsefe Terimleri Sözlügüu, İstanbul

Alayoğlu, N. (2015). "İş Ahlakı Ekseninde İnsan Kaynakları Yönetimi ve Etik", Güncel Yaklaşımlar Işığında Etik, Ed. Rana Atabay, N. Öykü İyigün, 1. Baskı, İstanbul, Beta Basım A.Ş.

Arvey, R.D., Davis, G.A., Nelson, S.M. (1984). "Use of Discipline in an Organization: A Field Study", Journal of Applied Psychology, Vol.69: 448-460.

Aşçıgil, S.F. (2001). "İş Etiği: Eski Sorunlar, Yeni Kavramlar, Yeni Yaklaşımlar"
(Tebliğ), Friedrich Ebert Stiftung Derneği Ekonomi Forumu, İstanbul

Bekmen, A. (2014). Sermayenin Etik İnşası: Küresel Üretim ve Kurumsal Sosyal Sorumluluk, 1. Basım, İstanbul, BÜTEK A.Ş.

Bentler, P.M., Bonnet, D.C. (1980). "Significance Tests and Goodness of Fit in the Analysis of Covariance Structures", Psychological Bulletin, 88(3): 588-606.

Berkman, Ü., Arslan, M. (2009). Dünyada ve Türkiye'de İş etiği ve Etik Yönetimi, İstanbul, TÜSİAD

Blome, C., Paulraj, A. (2013). "Ethical Climate and Purchasing Social Responsibility: A Benevolence Focus", Journal of Business Ethics, Vol.116, No.3: 567-585.

Carter, C.R. (1999). "Ethical Issues in International Buyer-Supplier Relationships: A Dyadic Examination", Journal of Operations Management, Vol.18: 191-208.

Carter, C.R. (2005). "Purchasing Social Responsibility and Firm Performance", International Journal of Physical Distribution \& Logistics Management, Vol.35, Issue.3: 177194.

Carter, C.R., Jennings, M.M. (2000). "Purchasing's Contribution to the Socially 


\section{C.. AFŞAROĞULLARI - O. KORKUT ALTUNA}

Responsible Management of the Supply Chain", Center for Advanced Purchasing Studies

Carter, C.R., Jennings, M.M. (2002). "Social Responsibility and Supply Chain Relationship", Transportation Research Part E, Vol.38, No.1: 37-52.

Carter, C.R., Jennings, M.M. (2004). "The Role of Purchasing in Corporate Social Responsibility: A Structural Equation Analysis", Journal of Business Logistics, Vo.25, Issue.1: 145-186.

Carter, C.R., Rogers, D.S. (2008). “A Framework of Sustainable Supply Chain Management: Movingtoward New Theory", International Journal of Physical Distribution \& Logistics Management, Vol. 38 Issue.5: 360387.

Chin, W.W. (1998a). "The Partial Least Squares Approach to Structural Equation Modeling", Modern Methods for Business Research, Ed. G. A. Marcoulides, Mahwah, NJ Lawrence Erlbaum Associates: 295-336.

Chin, W.W. (1998b). "Commentary: Issues and Opinion on Structural Equation Modeling", MIS Quarterly, Vol.22, No.1: vii-xvi.

Comrey, A.L., Lee, H.B. (1992). A First Course in Factor Analysis, Second Edition, Lawrence Erlbaum Associates, Hillsdale, New Jersey

Crane, A., Matten, D. (2010). Business Ethics, Third Edition, Oxford University Press, Oxford

Doğan, N. (2009). "İş Etiği ve İşletmelerde Etik Çöküş”, SÜ İİBF Sosyal ve Ekonomik Araştırmalar Dergisi, Sayı 16

Ferrell, O.C., Rogers, M.M., Ferrell, L., Sawayda, J. (2013). "A Framework for Understanding Ethical Supply Chain Decision Making," Journal of Marketing Channels, 20:34: 260-287.

Fornell, C., Larcker, D. (1981). "Evaluating Structural Equation Models with Unobservable Variables and Measurement Error", Journal of Marketing Research, 18: 3950.
Geoffrey, R.N., Streiner, D.L. (2008). Biostatistics: The Bare Essentials, Third Edition, BC Decker Inc, Hamilton

Goebel, P., Reuter, C., Pibernik, R., Sichtmann, C. (2012). "The Influence of Ethical Culture on Supplier Selection in the Context of Sustainable Sourcing", Int. J.Production Economics, Vol.140: 7-17.

Hair, J.F., Tatham, R.L., Anderson, R.E., Black, W. (1998). Multivariate Data Analysis, 5th Edition, Prentice Hall

Hegarty, W.H., Sims Jr., H.P. (1978). "Some Determinants of Unethical Decision Behavior: an Experiment", Journal of Applied Psychology, Vol.63: 451-457.

Henseler, J., Hubona, G., Ray, P.A. (2015). "Using PLS Path Modeling in New Technology Research: Updated Guidelines", Industrial Management \& Data Systems, Vol.116, Issue.1: 2-20.

Henseler, J., Ringle, C.M., Sinkovics, R.R. (2009). "The Use of Partial Least Squares Path Modeling in International Marketing", Ed. Rudolf R. Sinkovics, Pervez N. Ghauri, New Challenges to International Marketing, Advances in International Marketing, Vol.20: 277-319.

Hu, L., Bentler, P.M. (1998). Fit Indices in Covariance Structure Modeling: Sencivity to Underparameterized Model Misspecification, Psychological Methods, Vol.3, No.4: 424-453.

Luthra, S., Govindan, K., Kannan, D., Mangla, S.K., Garg, C.P. (2017). "An Integrated Framework for Sustainable Supplier Selection and Evaluation in Supply Chains", Journal of Cleaner Production, Vol.140, 1686-1698.

Milgram, S. (1974). Obedience to Authority: An Experimental View, Harper \& Row, New York

Neef, D. (2004). The Supply Chain Imperative: How to Ensure Ethical Behavior in Your Global Suppliers, New York, Amacom

Nunnally, J. (1978). Psychometric Theory, McGraw Hill, New York 
İzmir İktisat Dergisi (İzmir Journal of Economics) , Yıl:2019 Cilt:34 Sayı:2 ss. 171-189

Özgener, Ş. (2014). İș Ahlakının Temelleri, 3. Baskı, Ankara, Nobel Yayıncllık

Park, H., Stoel, L. (2005). "A Model of Socially Responsible Buying/Sourcing Decision-Making Processes", International Journal of Retail \& Distribution Management, Vol.33, No.4: 235-248.

Pitts, C. (1995). Motivating Your Organization, McGraw-Hill Book Company

Robin, D., Giallourakis, M., David, F., Moritz, T. (1989). "A Different Look at Codes of Ethics", Business Horizons, 32, 66-73.

Ross, T. (1988). Ethics in American Business, Detroit

Seuring, S., Müller, M. (2008). "From a Literature Review to A Conceptual Framework for Sustainable Supply Chain Management", Journal of Cleaner Production, Vol.16: 16991710.

Somers, M.J. (2001). "Ethical Codes of Conduct and Organizational Context: A Study of the Relationship Between Codes of Conduct, Employee Behavior and Organizational Values", Journal of Business Ethics, Vol.30, Issue.2: 185-195.

Tenenhaus, M., Amato, S., Vinzi, V.E. (2004). "A Global Goodness of Fit Index for PLS Structural Equation Modelling", Proceedings of the XLII SIS Scientific Meeting, CLEUP: Padova: 739-742.

Thornton, L.M., Autrey, C.W., Gligor, D.M. (2013). "Does Socially Responsible Supplier Selection Pay-Off for Customer Firms? A Cross Cultural Comparison", Journal of Supply Chain Management, Vol.9, Issue.3: 66-89.

Touboulic, A., Walker, H. (2015). "Theories in Sustainable Supply Chain Management: a Structured Literature Review", International Journal of Physical Distribution \& Logistics Management, Vol. 45, Issue.1/2: 16-42.

Trevino, L.K. (1990). "A Cultural Perspective on Changing and Developing Organizational Ethics", Research in
Organizational Change and Development, Vol.4: 195-230.

Trevino, L.K. (1992). "The Social Effects of Punishment in Organizations: A Justice Perspective", Academy of Management Review, Vol.17: 647-676.

Trevino, L.K., Butterfield, K.D., McCabe, D.D. (2001). "The Ethical Context in Organizations: Influences on Employee Attitudes and Behaviors", Ethical Issues in Organizations, The Next Phase of Business Ethics: Integrating Psychology and Ethics, Eds. Michael Schwartz, Howard Harris, Ron Duska, Emerald Group Publishing Limited: 301-337.

Trevino, L.K., Weaver, G.R. (2001). "Organizational Justice and Ethics Program "Follow-Through": Influences on Employees' Harmful and Helpful Behavior", Business Ethics Quaterly, Vol.11: 651-671.

Trevino, L.K., Weaver, G.R., Gibson, D.G., Toffler, B.L. (1999). "Managing Ethics and Legal Compliance: What Works and What Hurts", California Management Review, Vol.41: 131-151.

Trevino, L.K., Youngblood, S.A. (1990). "Bad Apples in Bad Barrels: A Causal Analysis of Ethical Decision-Making Behavior", Journal of Applied Psychology, Vol.75: 447-476.

Ülgen, H., Mirze, S.K. (2004). İşletmelerde Stratejik Yönetim, 2. Baskl, İstanbul, Literatür Yayıncılık

Weaver, G.R. (2004). "Ethics and Employees: Making the Connection", Academy of Management Executive, Vol.18, No.2: 121125.

Weaver, G.R., Trevino, L.K., Agle, B. (2005). "Ethical Role Models in Organizations", Organizational Dynamics, Vol.43: 313-340.

Weele, A.J.V. (2014). Satınalma ve Tedarik Zinciri Yönetimi, Çev. Timuçin Binder, 5. Basımdan Çeviri, İstanbul, Literatür Yayınları

Wetzels, M., Odekerken-Schröder, G., van Oppen, C. (2009). “Using PLS Path Modeling for Assessing Hierarchical Construct Models: 
Guidelines and Empirical Illustration", MIS

Quarterly, Vol. 33, No.1: 177-195.

\section{EKLER}

EK 1: Araştırmanın Değişkenlerine Ait Aritmetik Ortalama ve Standart Sapma Değerleri, Açımlayıcı Faktör Analizi Sonuçları ile Ölçeklerin Orijinal Faktör Yapılarının Karşılaştırması

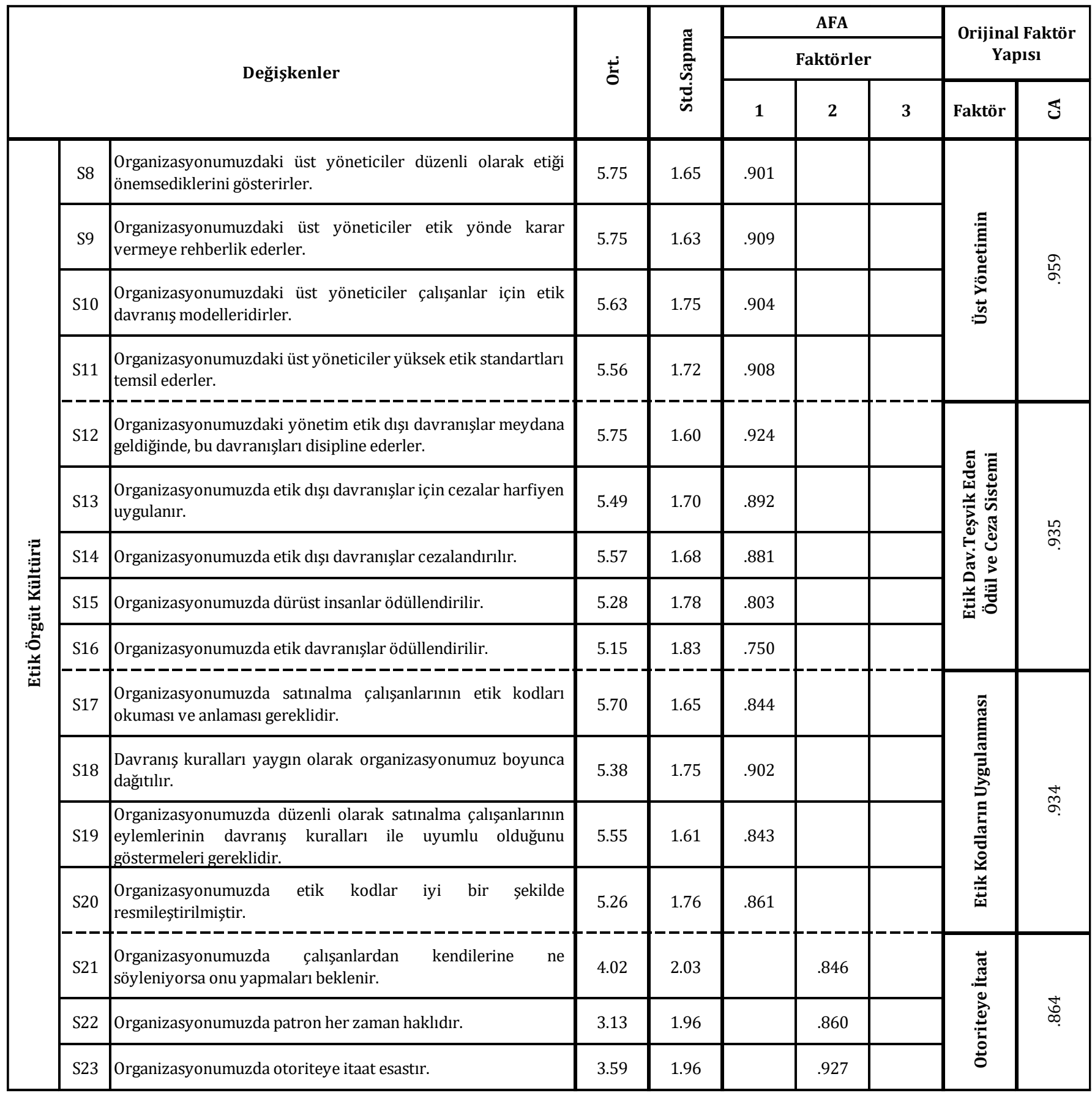


Devamı

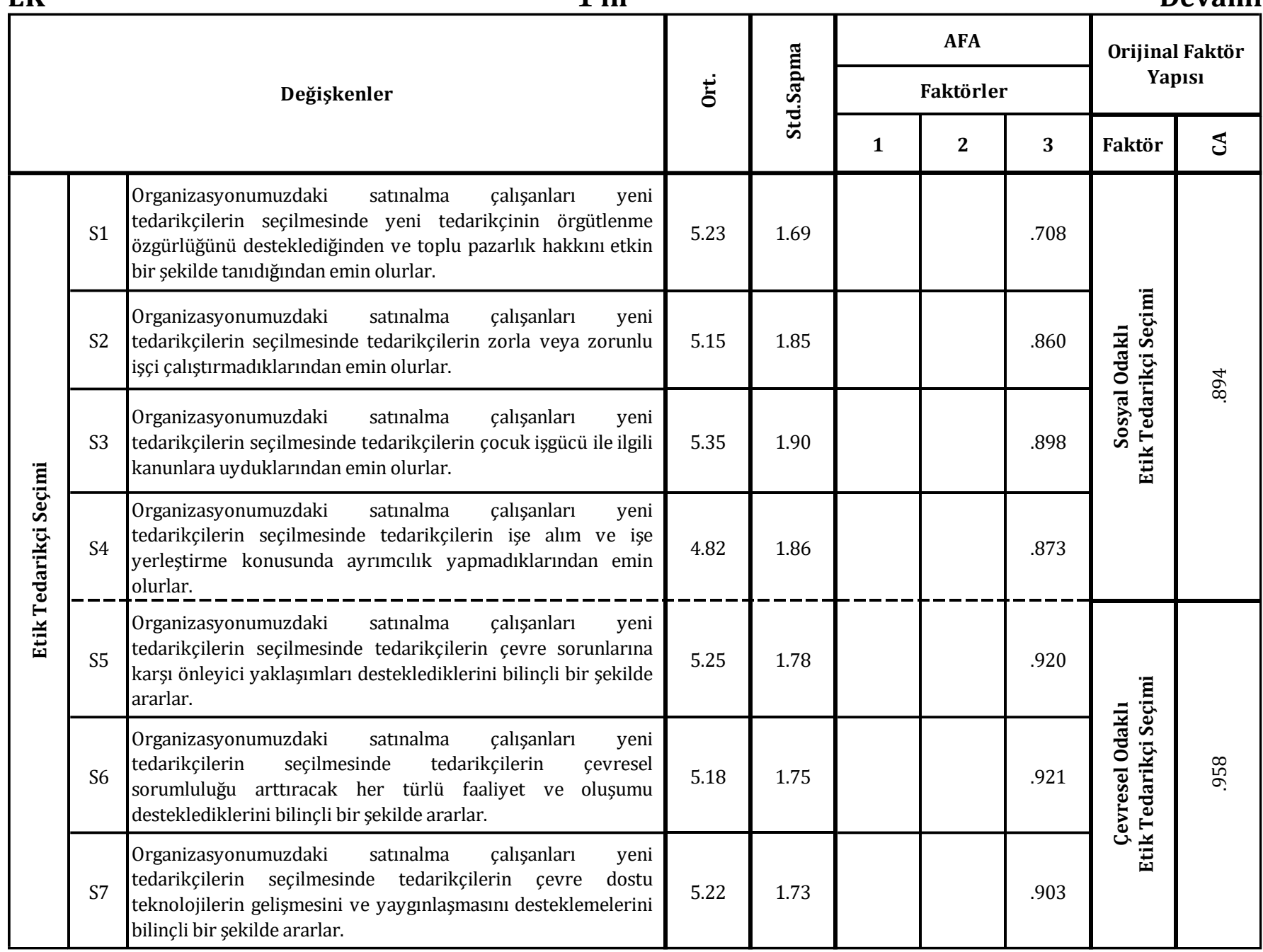

